\title{
URBAN WATER FUTURE: WHAT CAN WE LEARN FROM THE SINGAPORE EXPERIENCE?
}

\author{
Bambang Susantono ${ }^{1}$, Sarah Hui $\mathrm{Li}^{2 *}$ \\ ${ }^{1}$ Vice President of Knowledge Management, Asian Development Bank \\ ${ }^{2}$ Urban Development Consultant, Asian Development Bank
}

(Received: April 2021 / Revised: April 2021 / Accepted: May 2021)

\begin{abstract}
Asia and the Pacific region is a hot spot for water insecurity in the world. With water resources such as ground and surface water depleting, the demand for water consumption increases as urban population continues to grow. Meanwhile, non-revenue water (NRW) leads to inefficient water service delivery, waste of energy, drinking water contamination, loss of revenue, and increased operation costs. As the water stress continues in the region, what can cities in the region do to sustain their water future? To answer this question, this paper uses Singapore as an example and draws lessons from its urban water management experience. It finds that countries can take away from Singapore knowledge and practices, including institution autonomy paired with people-centric management, inter-agency coordination, emphasis on demand management, non-revenue water (NRW) regulation, as well as technologies and innovations. Apart from these, this paper also finds that the remaining water challenges faced by Singapore, such as climate change, energy dependence, and financial sustainability, are also shared by cities in developing Asia and Pacific countries. This paper therefore proposes solutions such as diversifying water sources and reducing NRW, increasing energy efficiency and exploring renewable energy, as well as engaging private sector investment as some of the first steps in tackling those shared challenges.
\end{abstract}

Keywords: Water insecurity; non-revenue water; Singapore; urban water future; people-centric management; urban water management; private sector investment

\section{INTRODUCTION}

Water is at the core of sustainable urban development. Without water, cities will not be able to sustain economic growth. Continuous urbanization, growing population, and intensified economic production have drastically increased the demand for water, while environmental degradation, natural disasters, and climate change are putting pressure on the supply of the already diminishing resource. It is estimated that the global economy loses $\$ 500$ billion USD per year due to water stress issues (OECD, 2012). Meanwhile, water is also a cross-sectoral issue that's linked to several global challenges such as public health. The recent coronavirus disease (COVID-19) pandemic has demonstrated the importance of water, sanitation, and hygiene services. For billions in the world to be able to wash hands with clean water and soap, governments must provide quality access to clean water for all population, especially the most vulnerable, in order to fight the virus. Water security is therefore an urban planning and policy issue that remains pivotal for cities thriving to become inclusive, sustainable, and livable.

*Corresponding author's email: shuili.consultant@adb.org

DOI: https://doi.org/10.32783/csid-jid.v4i1.220 
Asia and the Pacific region is a hot spot for water insecurity in the world, with around 600 million people still lacking access to basic water service (Asian Development Bank, 2016; UNICEF \& World Health Organization, 2019). To improve water security for cities in this region, it is crucial for policymakers to draw lessons from advanced economies. Singapore for instance has observed notable success from the management of their water. In 2007, Singapore won the prestigious Stockholm Industry Water Award for its "holistic approach to water resources management which made water use sustainable for different sectors of society in a unique and challenging urban island environment." While we can acknowledge the city-state's unique social, economic, and political nature, there are transferable lessons and takeaways from Singapore's urban water management story that can help to build a methodology available for others. Based on a rich reservoir of existing research, this paper contributes to this topic through discussing Singapore's latest water management updates and innovations, urban water management from similar utilities, as well as lessons and common future concerns that can serve as benchmarks in designing and managing future urban water utilities for developing Asian cities.

This paper proposes to examine Singapore's water journey in a systematic way, and identify key policy lessons for developing Asia and Pacific countries to achieve a sustainable water future. Based on site visits conducted by the Asian Development Bank in Oct 2019 in Singapore, as well as its years of practical experience assisting the region in water management, this paper aims to answer two questions: 1) how Singapore's urban water management has been effective, and 2) how cities in developing Asia and the Pacific countries can translate Singapore's experience for their own urban water development.

\section{URBAN WATER MANAGEMENT ISSUES IN ASIA AND THE PACIFIC REGION}

Rapid urbanization has brought significant economic growth to Asia and the Pacific region in the past decades. However, water security is still a concern. While a lot has been achieved over the years, 29 out of 48 economies in the region are still categorized as "water insecure" by 2016 (Asian Development Bank, 2016).

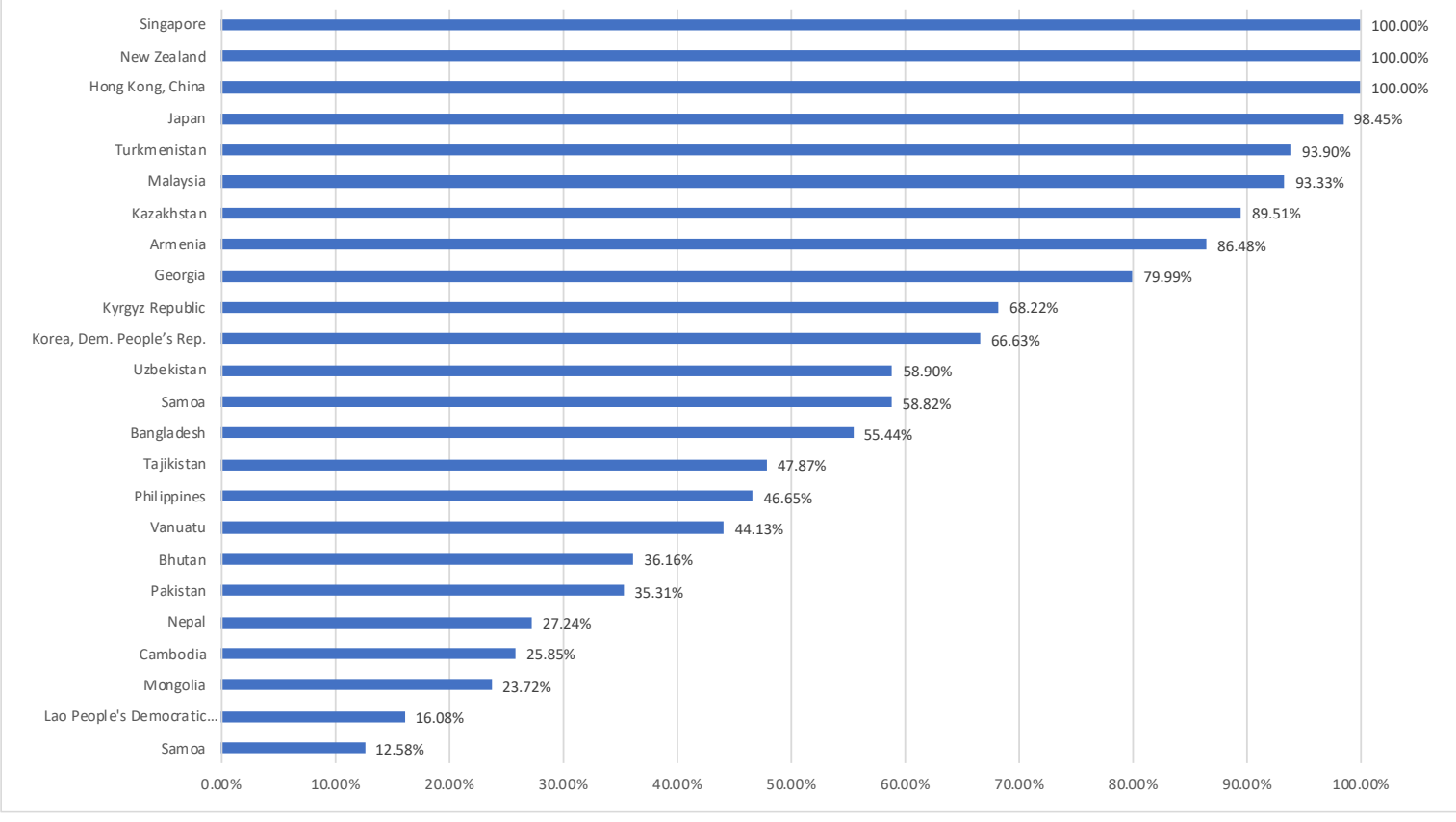

Figure 1 Percentage of population using safely managed drinking water services in Asia and Pacific countries (with available data) in 2017 (World Bank, n.d.). 
The coverage and reliability of water supply and service is the first concern. There is a population of 1.7 billion people in the region lacking access to basic sanitation (Asian Development Bank, 2016). Urban slum dwellers are among those who commonly lack access to clean water supply and sanitation, making slums the weak link of inclusive and sustainable urban development, especially during infectious disease outbreaks. The COVID-19 pandemic has further exhibited the importance of quality and inclusive urban infrastructure, including water, sanitation, and hygiene services, among others. Water resources are also depleting as the region has already accessed available surface and groundwater. Seven of the world's 15 biggest groundwater abstracting countries are in this region, especially in East and South Asia (Asian Development Bank, 2016). Even in urban areas in Asia where there's water supply, people do not always benefit from reliable supply available on a $24 * 7$ basis.

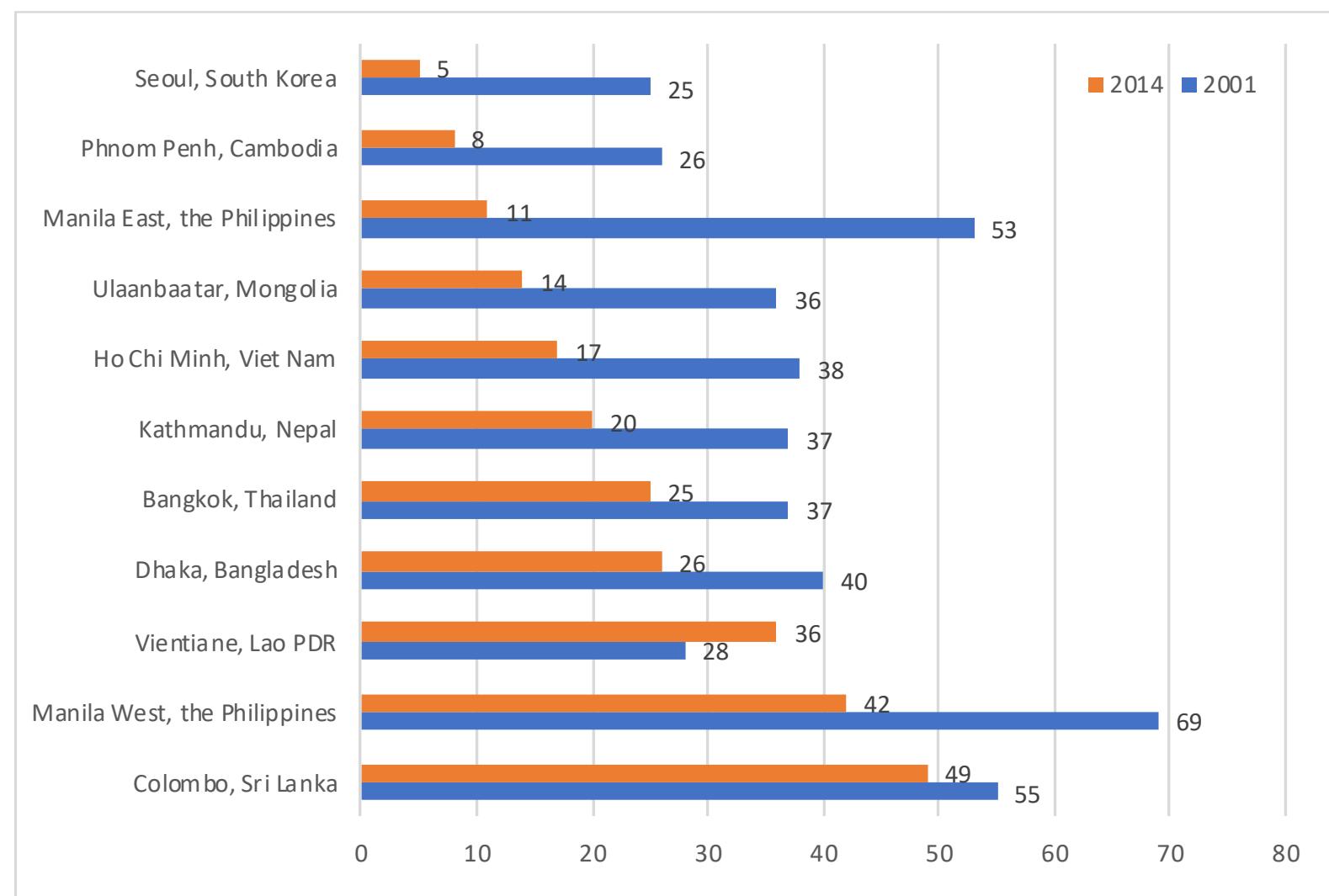

Figure 2 Percentage of Non-Revenue Water Levels in Selected Asian Cities (2001 and 2014) (Asian Development Bank, 2016)

Non-revenue water (NRW) is also a major problem in developing Asia and the Pacific countries and a cause of non-accessibility of water for end users. NRW measures the water lost in physical losses as leaks, and commercial losses as illegal connections. NRW in many cities is still above 50\% (Asian Development Bank, 2016). Even within countries, NRW can also vary. For example, in Malaysia, NRW varies from $18 \%$ to $73 \%$ among different states (Araral \& Wang, 2013). Reasons for high NRW include water leakage from aging infrastructure, inefficient operations and maintenance practices, poor metering system, and water theft. NRW can lead to inefficient water service delivery, waste of energy, drinking water contamination, loss of revenue, and increased operation costs (Araral \& Wang, 2013; Asian Development Bank, 2016). 
Meanwhile, the region's water demand is surging. Asia and the Pacific region is predicted to be home to 5.2 billion of the world's total population by 2050 , with an estimated 3.4 billion people living in water-stressed areas (Wiberg et al., 2017). As rapid urbanization and economic transformation continue, the region will host 22 megacities by 2030, burdening the already limited water resources (Asian Development Bank, 2016). Compounding these challenges, the region also faces increasing water-related natural disasters and climate impacts, adding pressure to existing water security issues. The region's water demand is projected to increase by about more than half, due to the growing needs for both domestic and non-domestic water usage, including manufacturing, agriculture, and thermal electricity generation (Asian Development Bank, 2016; OECD, 2012). Therefore, the need to secure the region's water future is urgent.

\section{HYPOTHESIS AND ANALYTICAL FRAMEWORK}

From the brief discussion of issues on urban water management in Asia and the Pacific, this paper proposes a simple hypothesis: the common goal of a water utility is to provide $100 \%$ water service coverage, and that despite some cities achieving $100 \%$ coverage, there are no common success elements, previous and remaining challenges, as well as governance mechanisms that apply to all.

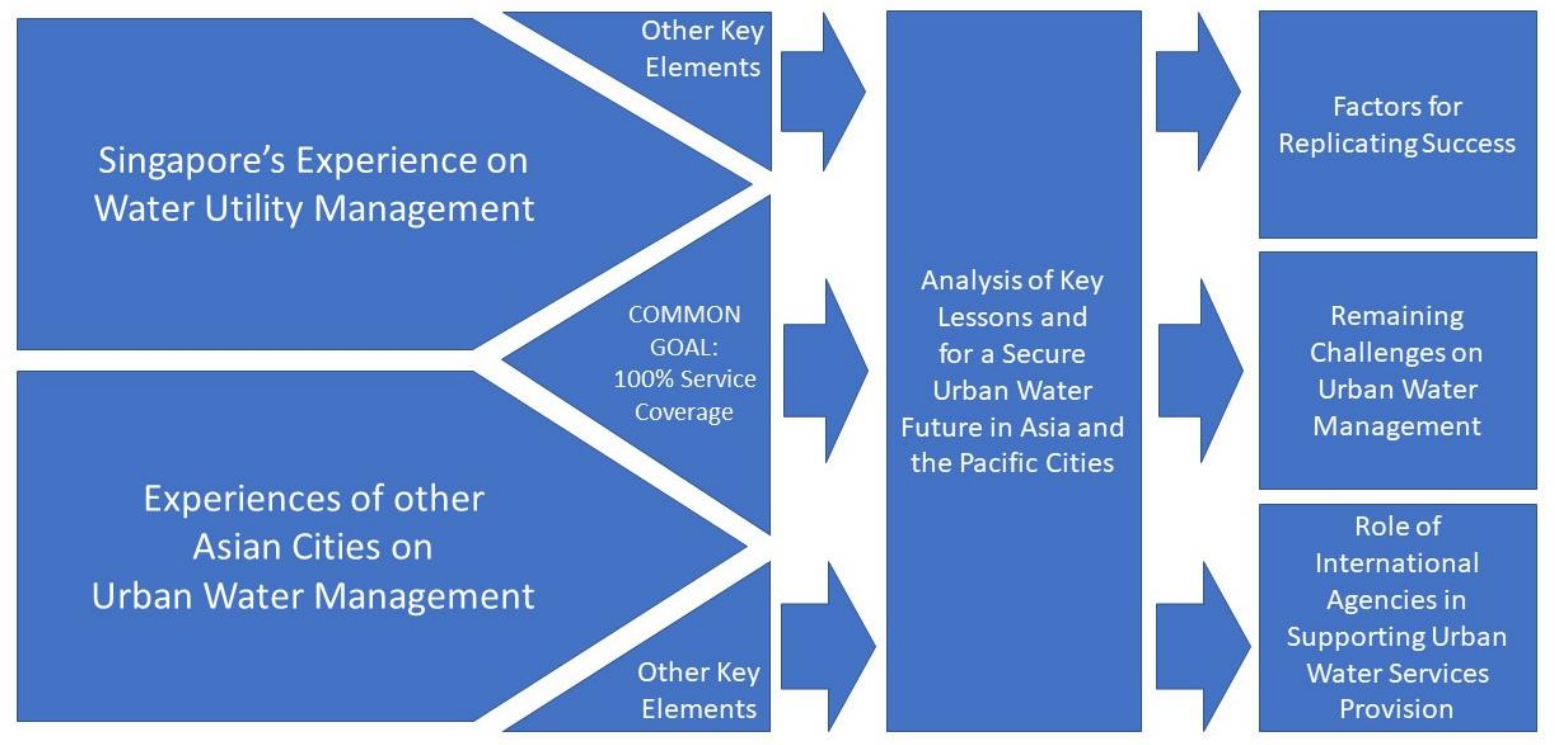

Figure 3 Analytical Framework (Asian Development Bank, n.d.)

Under this hypothesis, this paper implies an analytical framework taking the form of a jigsaw puzzle (Figure 3) to look into different key elements of Singapore and other successful water utilities in Asian cities with a common attained goal of having $100 \%$ water supply service coverage. Discussion about lessons learned from Singapore and other cities are then grouped into three main areas: factors for replicating success; remaining challenges, and the role of international agencies in supporting urban water service provision. The data in this paper came from literature review on historical and operational information on Singapore's water utility development, as well as observation and conversational data gathered from authors' visit to Singapore's water supply facilities.

\section{SINGAPORE'S URBAN WATER MANAGEMENT EXPERIENCE}

Today in Singapore, one can simply put a glass under a running tap and get clean drinking water. But just some 50 years ago, people still queued on streets for water during dry seasons. Having only three reservoirs meeting 20 percent of its demand at that time, Singapore relied the 
rest of its water supply on transfers from Malaysia. The two water agreements Singapore signed with Malaysia, one already expired, and the second one, which allows Singapore to withdraw 250 million gallons of water (1.14 million cubic meters) per day from Johor River, will expire in 2061 (Tortajada et al., 2013). While the independence accord guarantees the execution of the water agreement, Malaysia threatened to turn off the water supply if Singapore did not support its foreign policy (Luan, 2010). Singapore's water supply issue became a matter of national security.

Therefore, it was crucial for Singapore to gain water independence for its own survival. Since its independence, Singapore has adopted a holistic approach to transforming its water vulnerability into one of the world's best examples of water management.

\subsection{Supply Management}

Singapore embarked its water dependence path through diversifying its water sources. The current "four national taps", including water imported from Malaysia (up to 60\%), local catchment (10\%), desalination (up to $30 \%$ ), ${ }^{1}$ and NEWater or reclaimed water (up to $40 \%$ ), supply the country's water needs from both households and non-domestic sectors. The goal is for desalination and NEWater together to be able to supply $85 \%$ of Singapore's water demand by 2060 (Public Utility Board, 2016).

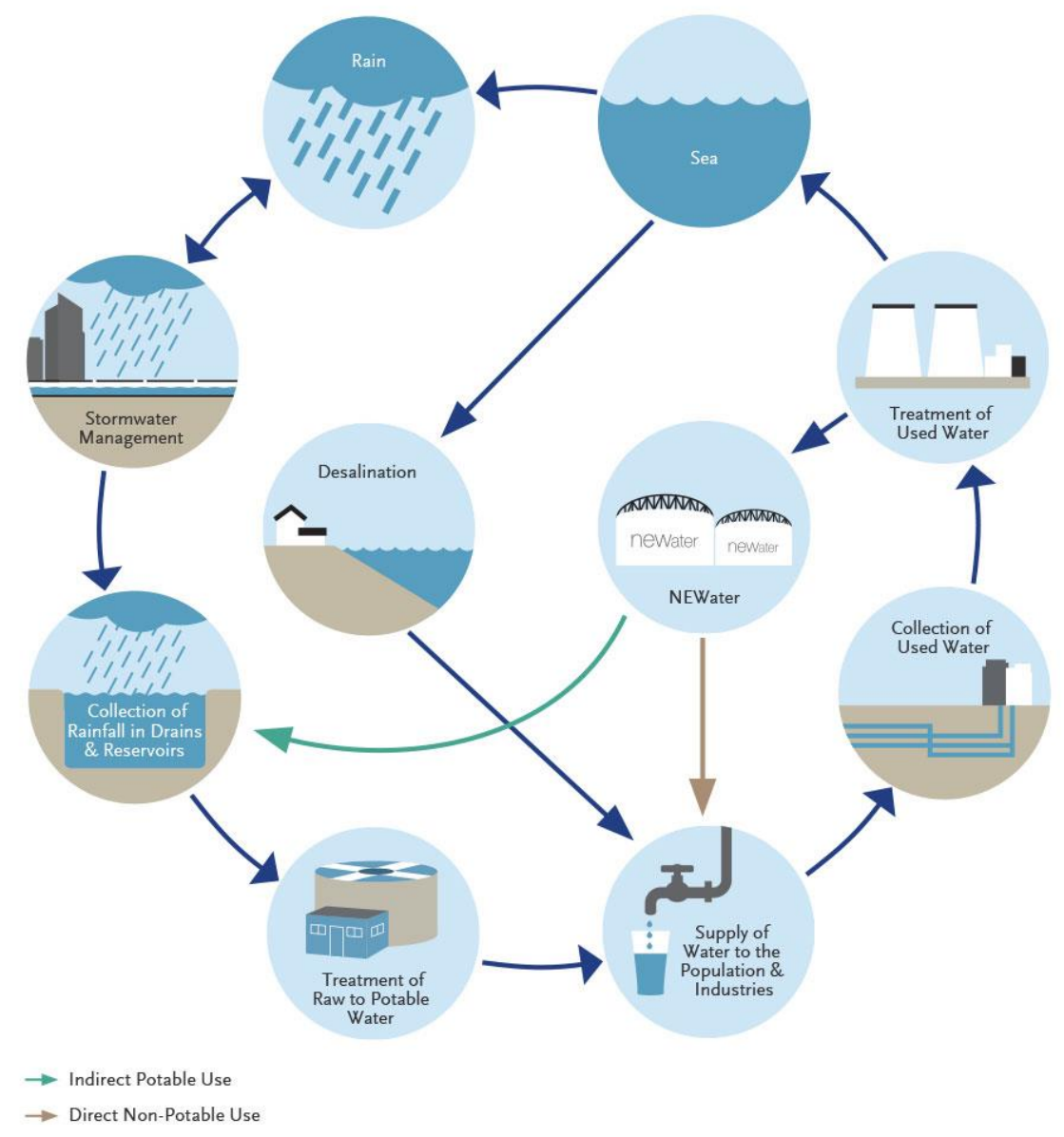

Figure 4 Singapore's water loop (National Council of Social Service, n.d.)

\footnotetext{
1 "Up to $30 \%$ " refers to Singapore is able to supply $30 \%$ of its water needs through desalination when operated in full (same for NEWater). Currently the country still relies more than $50 \%$ of its water supply on Malaysia.
} 
The Public Utility Board (2016), Singapore's national water authority, has summarized three key water policies for this successful diversification. First, ensuring every drop of water falling into Singapore is collected. Singapore has so far expanded its local water catchments into 17 reservoirs and a network of rivers, canals, and drains, together covering two-thirds of the island to ensure rainfall storage (Public Utility Board, n.d.-a). Second, positioning water as a reusable product that can be reclaimed. The catchment expansion process also separated Singapore's sewage and drainage system, which laid the groundwork for more efficient used water collection and treatment. And third, utilizing Singapore's surrounding natural resource seawater for desalination. Supported by these strategies, PUB has closed its water loop to make full use of its water resources.

\subsection{Demand Management}

Apart from managing water supply, Singapore has also been taking efforts in managing its water demand. Singapore currently needs about 430 million gallons of water a day (about 1.6 million cubic meters per day), with $45 \%$ and 55\% coming from domestic (households) and nondomestic (businesses) sectors respectively. The total demand in 2060 is estimated to double, with non-domestic sectors taking up $70 \%$ of the consumption. Singapore plans to supply this increased water demand mainly through NEWater and desalination (up to 85\%).

Singapore's water demand management policy instruments include pricing and non-pricing mechanisms such as public education (Qi et al., 2016). Water tariff in Singapore includes the cost of water production and supply, water conservation tax and waterborne fee, with Goods and Service Tax (GST) on top of the total price. For households, water tariff can vary between $\$ 2.01$ (monthly water usage less than $40 \mathrm{~m} 3$ ) to $\$ 2.71$ (after usage exceeds $40 \mathrm{~m} 3$ ) USD/m3 (PUB 2019e). This price is ranked the highest in Asia (Araral \& Wang, 2013; Danilenko et al., $2014)^{2}$. Meanwhile, PUB also encourages water conservation through water-saving campaigns, water efficiency awards, mandatory water efficiency labeling on household appliances (Public Utility Board, 2016). Through these measures, Singapore has reduced its water consumption from 165 liters per capita per day to 141 liters in 2018, and targeting 140 liters in 2030 (Public Utility Board, n.d.-c, 2016).

Another important aspect of demand management is Singapore's strategy in reducing nonrevenue water $(\mathrm{NRW})^{3}$, including commercial and physical losses in the water network. Singapore's entire water system is metered, from water supply to the consumer side (Tortajada \& Buurman, 2017). This means there are very few illegal connections and all water activities are monitored, minimizing water commercial losses. At the same time, more than 300 sensors installed islandwide monitor potable water pressure and detect early pipe burst (Public Utility Board, 2019). This helps reduce physical water losses due to pipe leaks. In 2018, Singapore's NRW is 5.6\% out of total water production, one of the lowest in the world (Public Utility Board, n.d.-c).

\subsection{Technology and Innovation}

Singapore's trajectory to water independence is also a constant path of pursuing better technology and innovation. Since 2002, Singapore together with many collaborators have

\footnotetext{
${ }^{2}$ According to PUB, despite the high price, the average household's water bill however remains a small portion of its income, considering factors such as subsidies and the country's income level.

${ }^{3}$ In Singapore, NRW is referred to as Unaccounted-for Water (UFW).
} 
invested \$724 million SGD (\$532 million USD) in water R\&D (Public Utility Board, n.d.-c). Some of the technologies and innovations are mentioned here. ${ }^{4}$

Reducing the cost of desalination through R\&D. Desalination is by far Singapore's most energy-intensive and therefore most expensive method to produce water (see Annex for details). Singapore's desalination adopts reverse osmosis (RO) technology for seawater treatment. Through the RO process, seawater is pushed through membranes to remove dissolved solids such as salts and minerals and produce pure drinking water. The RO technology currently requires about $3.5 \mathrm{kWh} / \mathrm{m}^{3}$. This means to process 100 cubic meters of seawater through $\mathrm{RO}$ technology, the electricity required is enough to power a $40 \mathrm{~W}$ fridge for about a year.

Validating technologies to improve energy efficiency in the water sector. Singapore has set up the Integrated Validation Plant (IVP) to test and validate new and innovative technologies such as advanced used water treatment before full deployment in the future. For example, the IVP demonstration process allows to not just treat used water, but also produce biogas and increase energy self-sufficiency. The process has also achieved the lowest energy consumption at $0.3 \mathrm{kWh} / \mathrm{m}^{3}$, compared to $0.5 \mathrm{kWh} / \mathrm{m}^{3}$ for conventional treatment.

Enhance efficiency and sustainability through smart technologies. PUB has set up a SMART PUB Roadmap to identify and integrate technologies for its water future. At the Integrated Validation Plant mentioned previously, data generated by smart cameras and environmental sensors are integrated into a platform, and artificial intelligence is adopted to alert potential abnormalities of the water system. This contributes to a less manual dependent water operation and reduced human error (Public Utility Board, 2019). It also helps to reduce the plant's energy costs by $5 \%$, according to PUB. ${ }^{5}$

Another important technology refers to Singapore's smart metering system. Currently, the country's 1.6 million water meters are read once every two months manually. ${ }^{6}$ With the Advanced Metering Infrastructure (AMI) enabled smart meter, water consumption can be read automatically several times a day, with data being transmitted daily back to PUB (Ai-Lien, 2019; Public Utility Board, n.d.-c). This will improve PUB's resource efficiency through minimizing manual meter readings, and contribute to the reduction of NRW. Customers will also be able to monitor their water consumption through a mobile application, with notifications of water leaks and high usage, which encourages water conservation behavior.

\section{URBAN WATER MANAGEMENT HIGHLIGHTS FROM OTHER CITIES IN THE REGION}

Today in Singapore, one can simply put a glass under a running tap and get clean drinking water. But just some 50 years ago, people still queued on streets for water during dry seasons. Having only three reservoirs meeting 20 percent of its demand at that time, Singapore relied the rest of its water supply on transfers

\subsection{Dhaka: Supplying Water for All}

The City of Dhaka went through a water service turnaround, with a special focus on supplying water for urban slums. The Dhaka Water Supply and Sewerage Authority (DWASA) was initially reluctant over supplying water to the poor, citing reasons such as the lack of necessity of individual connections and the inability of the poor to afford these services (Sharma \&

\footnotetext{
${ }^{4}$ Information in this section was gathered through field trips and conversations with PUB senior officials.

${ }^{5}$ Information gathered during ADB's site visits to PUB on 23 October 2019.

${ }^{6}$ Water bill is estimated during months when the bill is not read. If a customer is overcharged due to inaccurate estimation, he or she can submit meter readings for a refund.
} 
Alipalo, 2017). This mindset not only marginalized the vulnerable urban community, but also further threatened water pressure and public health condition in the city. As Dhaka is reliant on groundwater to constitute towards $80 \%$ of its water supply, the city is already facing an alarming groundwater depletion rate at 2-3 meters per year (Islam et al., 2018). Without proper water supply, there is a high likelihood that the impoverished would continue illegal pumping, resulting in the worsening of existing water pressure issues across the city (Sharma \& Alipalo, 2017). Meanwhile, without access to clean water and sound sanitation, urban slums are also exposed to infectious disease outbreaks, stressing public health conditions. Under a long from the Asian Development Bank (ADB), DWASA initiated projects to provide connections of safe drinking water supplies to slums. Moreover, based on ADB's project assessment, the high payment rate among two pilot slums was indicative that the poor value and were willing to pay for quality water access (Sharma \& Alipalo, 2017). For Dhaka, this shift in mindset towards its water management was a breakthrough that paved the way towards providing water for all.

Meanwhile, to sustain its water future, Dhaka is on also its trajectory of reducing dependency on groundwater and diversifying its water sources. DWASA plans to increase surface water supply, with measures such as increasing institutional capacity to attract investment and reducing surface water pollution (Islam et al., 2018; Sharma \& Alipalo, 2017).

\subsection{Phnom Penh: Reducing NRW is Key}

Phnom Penh managed to transform from a broken post-war water system to a modern aroundthe-clock citywide water supply. One notable success is the city's effort in NRW reduction. According to Phnom Penh Water Supply Authority (Phnom Penh Water Supply Authority., n.d.), several measures were implemented to reduce water loss, namely: a) updating and correcting its customer database to improve water bill collection rate; b) installing efficient and quality meters on all household connections, accompanied with a regular meter examination and replacement program, to measure water consumption accurately; c) upgrading and replacement of old pipes to prevent water leaks; d) establishing water leakage repair groups to ensure timely and quality repairment of water pipes; and e) provide training, as well as a punishment and rewarding system, to improve staff quality and prevent misconduct. These measures were seen as contributing factors that resulted in the reduction of NRW from $72 \%$ in 1993 to 8.2\% in 2018 (Phnom Penh Water Supply Authority., n.d.).

At the same time, PPWSA has also worked on increasing tariff to cover operation, maintenance, and asset depreciation costs. It's worth mentioning that PPWSA went through a few lessons before settling on its current policy to target the poor. The initial policy, which selling subsidized water to community representatives who in turn resold the water to the poor, failed due to corruption among community representatives and the collection amount was also too low (Biswas \& Tortajada, 2010). Instead of supply free water to the poor, the policy was transformed a targeted subsidy program, with extra efforts to inform and educate the poor, that allows households to repay the bill over a period of 10 to 20 months and receive $30 \%$ to $100 \%$ subsidy based on their financial ability (Biswas et al., 2021; Spencer \& Meng, 2019). Together with previous NRW efforts, PPWSA managed to recover costs and provide water across all income groups in Phnom Penh.

\subsection{Seoul: Infusing Technologies for Efficiency}

Having achieved $100 \%$ tap water supply coverage in 1991, Seoul has been utilizing digital technologies to improve water system efficiency and deal with new challenges. Similar to Singapore, the highly urbanized Seoul Metropolitan Area faces the issue of higher frequency of 
urban flooding as a result of change of climate (Choi, 2015). Pollution caused by urban flooding can damage Seoul's only water supply - Han River and further lead to issues like drinking water contamination. From the technology aspect, Seoul has deployed a supply control system that monitors water quality and pressure, a production control system that forecasts demand using weather and consumption data, a remote control system that collects and analyzes operation and purification points with CCTV, a Seoul Water New System that enables real-time water quality testing and control - all these are integrated into one GIS-based operation system named Arisu Combined Information System, helping the city provide timely response and decision-making over its water system, including its urban flooding challenges (The Office Of Waterworks Seoul Metropolitan Government, n.d.).

\section{LEARNING FROM SINGAPORE AND OTHER CITIES' URBAN WATER EXPERIENCE}

As mentioned previously, this paper will look into different key elements of Singapore and other successful water utilities in Asian cities. These key elements will be grouped into three main areas for discussion: factors for replicating success; remaining challenges, and role of international agencies in supporting urban water service provision.

\subsection{Transferring Success}

Having achieved 100\% tap water supply coverage in 1991, Seoul has been utilizing digital technologies to improve water system efficiency and deal with new challenges. Similar to Singapore, the highly urbanized Seoul Metropolitan Area faces the issue of higher frequency of urban flooding as a result.

Institutional autonomy and people-centric management enable efficient water management. Being the only authority in charge of all water affairs, the corporatized PUB has a high level of autonomy in designing and implementing water policies and initiatives without relying heavily on interdepartmental coordination. Similar water specialized agencies include previously mentioned PPWSA from Phnom Penh, DWASA from Dhaka, among others. This has contributed to both institutional efficiency and financial sustainability for PUB. Singapore's PUB was able to increase water tariff progressively and tap into the commercial market issuing bonds, generating cash for its own operations and other investments (Tortajada, 2006). Such autonomy also allows PUB to have a great say in its human resource management. Staff remuneration is benchmarked against Singapore's civil service, which is in turn benchmarked against the market. Such a competitive benefits package creates strong incentives for employee performance. Meanwhile, staff are also provided with training opportunities, which contributes to staff self-development and therefore organizational competency as a whole (Public Utility Board, n.d.-c; Tortajada, 2006).

Water management also takes inter-agency efforts. While PUB has full ownership of the entire water system in Singapore, integrating water into long-term sustainable planning requires institutional coordination across government agencies. In the 1970s, Singapore initiated the movement to clean up the Singapore River, and coordinated among environment, housing, industry, land planning and other agencies. The river clean-up wouldn't be successful without inter-agency implementation. PUB's current water treatment technology testing, such as the codigestion mentioned earlier, also relies on the National Environmental Agency to provide testing materials such as waste food. As water is the essential element cutting across all industries and sectors, inter-agency coordination provides enabling environment and institutional support for integrated water management.

Managing demand is as important as managing water supply. With increasing water demand due to population growth as well as diminishing supplies result from changing climate, 
cities have come to realize the importance of water consumption management. Just recently, the historical sharp fall of Mekong River levels due to dry season has made aware the government of Cambodia and its residents of the urgent need for water conservation. The COVID-19 pandemic has further called for water resource conservation as one of the pathways to a lowcarbon and resilient future (Asian Development Bank, 2020b). For Singapore, its "valuing water" demand management is viewed as crucial to its success (Tortajada, 2006). Pricing is an important tool in regulating water demand in Singapore. Data shows that block water tariff increase has become an effective instrument in influencing consumer behavior and has contributed to an overall decrease in water consumption in Singapore. To emphasizing water as a scarce and precious resource, a progressive tariff reform in 1997 increased the water price by $120 \%$ (rolled out over a four-year period), created strong incentives for water conservation. In 2017, Singapore announced another round of tariff increase (30\%) due to the increasing cost of water supply (Min, 2017). In addition, 30\% of the total water tariff consists of the water conservation tax, ${ }^{7}$ which further stresses the importance of water saving. Compared to before the 1990s, when the tariff was designed to only recover the cost of water supply, today's water tariff in Singapore reflects the higher prices of alternative supply methods such as desalination. For developing Asian countries, the effectiveness of Singapore's tariff transformation suggests that water, while being an essential daily good, can be charged based on economic efficiency and be used to regulate consumer behavior with social considerations as explained hereafter.

Water pricing needs to consider equity. Inequality exists in water bills. In developing countries, the poor often have to purchase bad quality water at a higher price from water vendors due to unstable water supply and services in their areas. Apart from solutions such as ensuring coverage, the water tariff structuring should balance affordability and sustainability to account for equity. While Singapore has the highest water price in Asia, it also provides rebates (called U-Save Program) for households who cannot afford to pay the current tariff. During COVID-19 pandemic, Singapore government also provided rebates through U-Save to residents living in public housing, to support utility payments during disruptive times (Government of Singapore, 2020). Multiple research also confirms that instead of providing subsidized water for all and potentially benefiting the wealthiest more, targeted subsidies for the poor are more efficient in achieving equity (Connor, 2015; Tortajada, 2006; Wichelns, 2013). The previously discussed practices from Dhaka and Phnom Penh provide further evidence supporting this view.

Regulating NRW is important for sustainable water management. In reducing NRW, Singapore has over the years ensured a $100 \%$ coverage of its metering system, as well as gradually replaced old and leaking pipes (Araral \& Wang, 2013). The country also addresses NRW challenges through asset management. From forming a good understanding of the age of the pipes, to conduct annual checks for all pipes, to deploy sensors to monitor water pressure, and to implement risk-based asset management software to schedule pipe replacements, PUB is building its ability to anticipate and react to network failure while minimizing interruptions to water operations. Meanwhile, digital technology is also utilized to increase metering accuracy in order to further reduce NRW. These technical solutions are coupled with regulatory tools including legislation for non-compliance, as well as the demand management zones approach, to better regulate and monitor water consumption and NRW (Araral \& Wang, 2013; Tortajada $\&$ Buurman, 2017). These measures are not new nor unique to Singapore, but they require effective governance to turn ideas into implementation. The successful transformation of Phnom Penh's water supply has proven that developing Asian cities can also achieve

\footnotetext{
${ }^{7}$ For domestic consumption, if the monthly consumption is over 40 cubic meters, the water conservation tax is increased to $45 \%$ of the total price.
} 
remarkable NRW reduction results with good governance. Developing countries in the region can draw from these lessons for their own NRW management.

Innovation is more than technological innovation. To start with, it is important to build data infrastructure and data management capacity as part of the enabling environment for more and better use of innovative solutions. In Singapore and Seoul's cases, the two water utilities were able to transform into smart water management through digitizing water infrastructure, harness quality data, creating digital database, and translating numbers into information that informs more efficient and effective evidence-based decision-making, and leveraging more cutting-edge solutions such as GIS mapping, artificial intelligence, and digital twin (Jun, 2014; Public Utility Board, 2020). In comparison, most developing Asian and Pacific cities still lack water-related data and information, resulting in limited water and sanitation services, water resources management, and water-related disaster information systems (Asian Development Bank, n.d.). Enhancing water-related data production and management can be the first step towards improving urban water management for developing Asian cities.

Other than innovative technology, institutional adaptability can facilitate technological development for water management. One good example is PUB's revisit to the possibility of using desalination after technology evolved, instead of insisting on its initial assessment years ago (Qi et al., 2016). Instead of maintaining the status quo, it is useful for governments to be adaptive, revisit, and update water planning as technology improves. Meanwhile, innovation can also be about facilitating private sector engagement. Apart from technology and R\&D, Singapore has also been innovating in creating the ecosystem for engaging the private sector. The example here is the Singapore Water Exchange (SgWX). Launched in 2018, SgWX is a designed space for water companies along the water value chain to operate and collaborate, and therefore push water innovation and industry growth (Public Utility Board, n.d.-b). Similarly, Seoul has also established Waterworks Research Institute, focusing on developing new technology that contributes to Seoul's sustainable water supply (The Office Of Waterworks Seoul Metropolitan Government, n.d.). Innovations like these add to the enabling environment for better water management in urban areas.

\subsection{Remaining water security challenges shared by Singapore and other countries} Changing weather patterns affect water supply and service reliability. The Centre for Climate Research Singapore has projected that Singapore will experience hotter temperatures, as well as more extreme dry season and rainfalls (Public Utility Board, 2016). Compared to its 1981-2010 long-term average, Singapore's rainfall recorded in 2018 was about 21\% lower (Meteorological Service Singapore, 2018). The same issue could also affect the Johor River next door, which Singapore draws daily water from. In tackling this, Singapore's strategy is to diversify $85 \%$ of its water supply coming from desalination and NEWater by 2060, and therefore reducing its dependence on rainwater. While most developing countries in this region, unlike Singapore, are blessed with natural water resources, it doesn't mean water scarcity would not become an issue in the near future. Singapore's unique situation can inspire cities to conduct future thinking and prepare for potential water security issues through measures like securing additional water resources (such as water reclamation) to reduce water shortage risks, and in parallel to reduce NRW to acceptable levels and to manage water demand.

Another challenge brought by urbanization and changing climate is urban flooding. For cities where water supply relies heavily on surface water, changing rain patterns could increase the frequency of floods and droughts, therefore impact water resources in the region (Asian Development Bank, 2016). Both Dhaka and Phnom Penh's flood risk management are supported by city-level masterplans for sewerage and drainage systems. Singapore is also 
working on widening and deepening its waterways to reduce flash flood risks, and considering rising ground levels and installing flood barriers to protect itself from rising sea levels and storm surges (Public Utility Board, 2016). Seoul, on the other hand, has taken a step further and gone beyond government-led flood control measures. Apart from traditional flood control measures that typically consist of above-mentioned structural measures (such as sewage system expansion, rainwater pumping) and non-structural measures (such as flood maps, evacuation plans), Seoul's comprehensive approach also brings in private sector insurance to ease the financial burden of previously government-funded disaster compensation (Choi, 2015). The previously mentioned water quality control technology and Combined Information System adopted by Seoul can also contribute to monitoring water quality during flood season to prevent and respond to water contamination.

The growing energy demand as water demand increases. With Asia and Pacific's rapid urbanization and urban population growth, the region's water demand is projected to increase by $30-40 \%$, with much of the region's existing groundwater resources already being fully utilized (Asian Development Bank, 2016). Meeting such demand under the impact of climate change requires solutions such as desalination and water reclamation, which requires a substantial amount of energy. For countries like Singapore, balancing water independence and energy dependence is a challenge. Research argues that while there's a trade-off, compared to water sources, energy dependence is more flexible as it can be purchased from the international market. Besides Singapore, other countries in the region such as India and Australia have also pioneered in energy reduction and water filtration technologies (World Bank, n.d.). Meanwhile, study also suggests that energy-efficient building retrofitting can contribute to both water and energy conservation while lowering greenhouse gas emissions (International Finance Corporation, 2021). It is worth for developing Asian countries to also be aware of the growing energy demand and look into energy efficiency, renewable energy, as well as waste-to-energy solutions for their urban water management.

Sustainable water management requires sustainable financing. For Singapore, this means the trade-off between water independence and affordability, as energy and technology costs grow. Singapore Government (n.d.) listed that it cost $\$ 1.3$ billion SGD to operate the water system in 2015, which was three times more than in 2000. For developing countries in the region, ADB (2017) estimated an $\$ 800$ billion USD climate adjusted investment needs for water and sanitation infrastructure from 2016-2030. Among current water investments, 98\% came from the public sector (Asian Development Bank, 2017). This calls for the significant need to unleash private capital investment. Public-private partnership, green finance, blended finance are some of the ways to mobilize the private sector and bring in benefits such as cost reduction, asset management, and capacity building for water infrastructure financing (Bessadi \& Cardascia, 2019; Cardascia, 2019). Meanwhile, as post-COVID recovery calls for more resilient cities, investing in climate-smart and nature-based urban infrastructure, such as wetlands, mangroves, and other green spaces, not only can provide urban flood protection and purify water supply, but also can bring positive socio-economic impacts, generating both investment and employment opportunities as well as improving quality of life (International Finance Corporation, 2021).

\subsection{The role of international development agencies}

International development agencies such as multilateral development banks are an important source for financing infrastructure. Like developing Asian countries, during the 1960s and 70s, the then under-developed Singapore received 14 loans from the World Bank, mostly focusing on infrastructure development, including projects to construct and improve water supply, sewerage systems, and water treatment plants (World Bank, n.d.). Both Phnom Penh and Dhaka, as well as other developing countries in this region, received loans, technical assistance, 
and capacity building support from the Asian Development Bank (ADB) for improving their urban water utilities. Multilateral development banks can also help catalyze private sector investments through other financial instruments such as credit guarantee. ADB has recently opened its Singapore office to assist mobilizing private sector funding to infrastructure and social development projects in the region (Asian Development Bank, 2019).

International development agencies also contribute to better urban management through designing efficient projects incorporating these learnings. These include insisting on developing people and organizational skills, improving managerial capacity, introducing operations, maintenance and asset management practices, as well as efficient technology adapted to the context. This highlights the importance of knowledge sharing through papers and blogs as the present one. While financing water infrastructure projects, development agencies such as ADB are also harnessing valuable success and failing practices from different country contexts. Knowledge products such as Water Insecurity and Sanitation in Asia ${ }^{8}$ as well as Asia Water Development Outlook ${ }^{9}$ provide insightful performance indicators, evaluations, and recommendations for water management in Asia and the Pacific region. During the COVID-19 pandemic, agencies like ADB also provided post-COVID recovery guidance for cities, outlining the importance of ensuring smooth and pro-poor urban water operations in cities' immediate response actions, as well as continuing to invest in resilient and quality water supply and wastewater services in the longer term (Asian Development Bank, 2020a). Through documenting and sharing such knowledge and practices, international development agencies add values to policy, institutions, and infrastructure development for the region's secure water future.

\section{CONCLUSION}

Singapore's urban water management has been bearing fruits thanks to its holistic planning, supply and demand management, as well as its constant efforts in technology advancement and innovation. Although Singapore's urban water management model is unique due to the country's political and geographical structure, developing countries in Asia and the Pacific region can still draw knowledge and practices from Singapore as well as other cities' experience. This includes learning from their successes such as institutional autonomy and people-centric management, inter-agency coordination, water demand management, tariff inclusiveness, NRW reduction and regulation, and innovations. It also means drawing lessons from Singapore's remaining challenges that are shared by cities in developing countries, including climate impacts, energy dependence, and the concern of financial sustainability. Meanwhile, by incorporating these learnings into infrastructure projects and knowledge products, international development agencies can play a positive role in facilitating better urban water management in the Asia and Pacific region.

This paper faced a number of limitations, include self-reported data from field trips and conversations with Singapore PUB senior officials, which could lead to biases; and potentially outdated information due to limited access caused by COVID-19. Building on these, future research can study ways to enhance water-related data availability and data infrastructure in urban water management, or dive into the financing aspect of urban water management and offer sustainable financing options for achieving water security in developing Asian and Pacific cities.

\footnotetext{
${ }^{8}$ Water Insecurity and Sanitation in Asia: https://www.adb.org/publications/water-insecurity-and-sanitation-asia

${ }^{9}$ Asia Water Development Outlook: https://www.adb.org/publications/asian-water-development-outlook-2016
} 


\section{ACKNOWLEDGEMENT}

The authors would like to thank Stephane Y. Bessadi, Senior Water Utility Specialist and Aldrin B. Plaza, Urban Development Officer at Sustainable Development and Climate Change Department (SDCC), Asian Development Bank.

\section{Annex: Reduce the energy cost of desalination through R\&D}

Singapore's desalination plants are still powered by national grids. At Tuas Desalination Plant, Singapore's 3rd desalination plant, while there are solar panels installed, the electricity produced is not yet enough to power the desalination process but only administrative use. PUB (2016) estimated if the technology maintains the status quo, desalination's energy consumption will quadruple in 2060.10 In tackling this, PUB is currently researching on Electro-deionization technology, which adopts electric field to pull dissolved salts from seawater and demonstrates an achievable energy consumption of $1.65 \mathrm{kWh} / \mathrm{m} 3$ (PUB 2016). Another potential solution could be biomimicry, which mimicks biological processes such as mangrove plants filtering and extracting fresh water from seawater using almost zero energy. One biomimicry technology is the membrane enhanced by aquaporin, a type of protein that blocks salt when water is pushing in an out of cells. A research team at Singapore's Nanyang Technology University has proved that aquaporin-based membranes can save energy in wastewater treatment and is yielding promising results in applying the technology in enhancing RO process in desalination (Li, et al. 2019; Qi, et al. 2016).

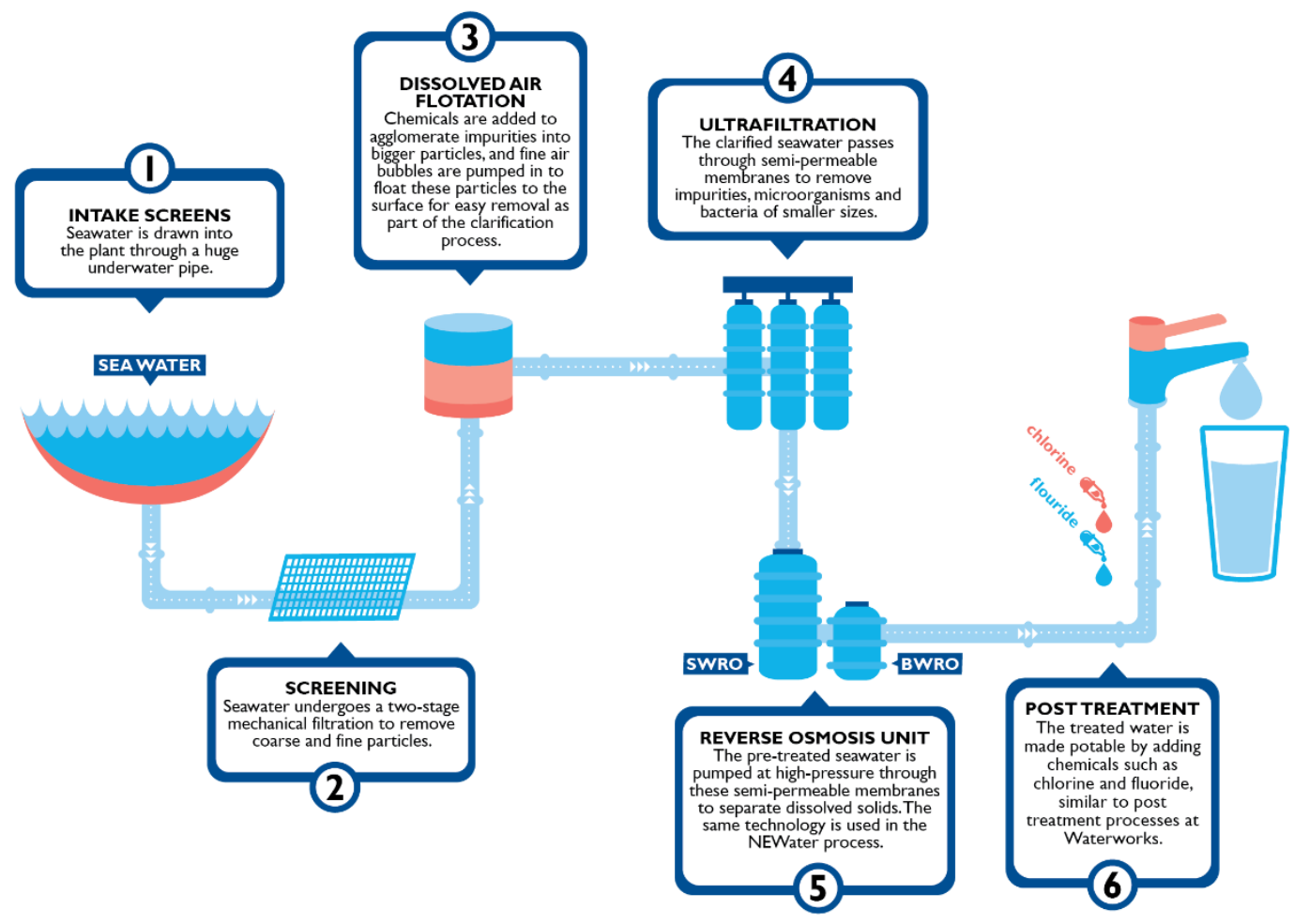

Figure 3 The desalination process at Tuas Desalination Plant, Singapore's $3^{\text {rd }}$ desalination plant that can produce 30 million gallons of water per day (PUB)

\footnotetext{
${ }^{10}$ Currently Singapore has three desalination plants, and two more to be finished building by 2020 .
} 


\section{REFERENCES}

Ai-Lien, C. (2019, April 12). Smart water meters to be rolled out to 300,000 properties here to help save water, Singapore News \& Top Stories - The Straits Times. https://www.straitstimes.com/singapore/smart-water-meters-to-be-rolled-out-to-300000properties-here-to-help-save-water

Araral, E., \& Wang, Y. (2013). Water demand management: Review of literature and comparison in South-East Asia. In International Journal of Water Resources Development (Vol. 29, Issue 3, pp. 434-450). https://doi.org/10.1080/07900627.2013.826413

Asian Development Bank. (n.d.). Asian Water Development Outlook 2020: Advancing Water Security across Asia and the Pacific . Retrieved May 20, 2021, from https://www.adb.org/publications/asian-water-development-outlook-2020

Asian Development Bank. (2016). Asian Water Development Outlook 2016: Strengthening Water Security in Asia and The Pacific. Asian Development Bank. https://www.adb.org/sites/default/files/publication/189411/awdo-2016.pdf

Asian Development Bank. (2017). Meeting Asia's Infrastructure Needs. https://www.adb.org/publications/asia-infrastructure-needs

Asian Development Bank. (2019). ADB to Open New Singapore Office to Expand Private Sector Operations . https://www.adb.org/news/adb-open-new-singapore-office-expandprivate-sector-operations

Asian Development Bank. (2020a). Livable Cities: Post-COVID-19 New Normal. https://www.adb.org/sites/default/files/institutional-document/624566/guidance-note-livablecities-post-covid-19.pdf

Asian Development Bank. (2020b, August 12). COVID-19 Recovery: A Pathway to a LowCarbon and Resilient Future . https://voxeu.org/article/urgently-needed-global-green-newdeal.

Bessadi, S., \& Cardascia, S. (2019). Practical examples to increase financing flows for waterrelated investments in Asia. https://www.oecd.org/water/Session7.Practical_example_to_increase_financing_flows_for_ water.pdf

Biswas, A. K., Sachdeva, P. K., \& Tortajada, C. (2021). Phnom Penh Water Story. Springer Singapore. https://doi.org/10.1007/978-981-33-4065-7

Biswas, A. K., \& Tortajada, C. (2010). Water supply of Phnom Penh: An example of good governance. International Journal of Water Resources Development, 26(2), 157-172. https://doi.org/10.1080/07900621003768859

Cardascia, S. (2019). Financing Water Infrastructure and Landscape Approaches in Asia and the

Pacific. https://www.oecd.org/water/Session4.Financing_Water_Infrastructure_and_Landscape_App roaches_in_Asia_and_the_Pacific .pdf

Choi, Y. J. (2015). Water Management Policy of the City of Seoul. https://www.seoulsolution.kr/en/node/3575

Connor, R. (2015). The United Nations world water development report 2015: water for a sustainable world . UNESCO Digital Library. https://unesdoc.unesco.org/ark:/48223/pf0000231823

Danilenko, A., van den Berg, C., Macheve, B., \& Moffitt, L. J. (2014). The IBNET Water Supply and Sanitation Blue Book 2014: The International Benchmarking Network for Water and Sanitation Utilities Databook. In The IBNET Water Supply and Sanitation Blue Book 2014: The International Benchmarking Network for Water and Sanitation Utilities Databook. The World Bank. https://doi.org/10.1596/978-1-4648-0276-8

Government of Singapore. (n.d.). Every drop counts. Retrieved May 21, 2021, from https://www.gov.sg/features/every-drop-counts 
Government of Singapore. (2020). 5 Government initiatives you may benefit from this year-end. https://www.gov.sg/article/5-government-initiatives-you-may-benefit-from-this-year-end

International Finance Corporation. (2021). A Green Reboot for Emerging Markets: Key Sectors for Post-COVID Sustainable Growth. https://www.ifc.org/wps/wcm/connect/26f79a1b-c191494b-b2d9-c891e138bb37/IFC_GreenReport_FINAL_web_1-1421.pdf?MOD=AJPERES\&CVID=ns1JVaR

Islam, M. M., Karim, M. R., Zheng, X., \& Li, X. (2018). Heavy metal and metalloid pollution of soil, water and foods in Bangladesh: A critical review. In International Journal of Environmental Research and Public Health (Vol. 15, Issue 12). https://doi.org/10.3390/ijerph15122825

Jun, C. Y. (2014). Efficient Drinking Water Supply System. https://www.seoulsolution.kr/sites/default/files/policy/03_Efficient Drinking Water Supply System_final.pdf

Luan, I. O. B. (2010). Singapore water management policies and practices. International Journal of Water Resources Development, 26(1), 65-80. https://doi.org/10.1080/07900620903392190

Meteorological Service Singapore. (2018). 2020 Climate and Weather: The Year in Review. http://www.weather.gov.sg/wp-content/uploads/2021/01/The-Year-in-Review-2020.pdf

Min, C. H. (2017). Singapore Budget 2017: Water prices to increase by 30\% from July 1 in two phases. https://www.straitstimes.com/singapore/singapore-budget-2017-water-prices-toincrease-by-30-from-july-1-in-two-phases

National Council of Social Service. (n.d.). Water Resource Management. Retrieved May 20, 2021, from https://www.nccs.gov.sg/singapores-climate-action/water-resource-management/

OECD. (2012). Meeting the Water Reform Challenge - OECD. https://www.oecd.org/env/resources/meetingthewaterreformchallenge.htm

Phnom Penh Water Supply Authority. (n.d.). Non-Revenue Water. Retrieved May 20, 2021, from https://www.ppwsa.com.kh/en/index.php?page=non-revenue-water

Public Utility Board. (n.d.-a). PUB Water from Local Catchment. Retrieved May 21, 2021, from https://www.pub.gov.sg/watersupply/fournationaltaps/localcatchmentwater

Public Utility Board. (n.d.-b). Singapore Water Exchange. Retrieved May 21, 2021, from https://www.pub.gov.sg/sgwx/about

Public Utility Board. (n.d.-c). Smart Water Meter Programme . Retrieved May 20, 2021, from https://www.pub.gov.sg/smartwatermeterprogramme/about

Public Utility Board. (2016). Our Water, Our Future.

Public Utility Board. (2019). Innovation in Water, Singapore. https://www.pub.gov.sg/Documents/Issue 11_Innovation in Water, Singapore_Full PDF.pdf

Public Utility Board. (2020). Digitalising Water - Sharing Singapore's Experience. IWA Publishing. https://www.iwapublishing.com/books/9781789061864/digitalising-water-sharing-singapore's-experience

Qi, S., Wang, R., Chaitra, G. K. M., Torres, J., Hu, X., \& Fane, A. G. (2016). Aquaporin-based biomimetic reverse osmosis membranes: Stability and long term performance. Journal of Membrane Science, 508, 94-103. https://doi.org/10.1016/j.memsci.2016.02.013

Sharma, M., \& Alipalo, M. (2017). The Dhaka Water Services Turnaround (M. Sharma \& M. Alipalo (eds.)). https://doi.org/10.22617/TCS179117-2

Spencer, J. H., \& Meng, B. (2019). Resilient urbanization and infrastructure governance: the case of the Phnom Penh Water Supply Authority, 1993-2007. Water Policy, 21(4), 848-864. https://doi.org/10.2166/wp.2019.211

The Office Of Waterworks Seoul Metropolitan Government. (n.d.). Seoul's tap water. Retrieved May 21, 2021, from https://arisu.seoul.go.kr/sudo_eng/sub/arisu/arisu01.jsp

Tortajada, C. (2006). Water management in Singapore. International Journal of Water 
Resources Development, 22(2), 227-240. https://doi.org/10.1080/07900620600691944

Tortajada, C., \& Buurman, J. (2017). Water Policy in Singapore. https://www.pub.gov.sg/watersupply/singaporewaterstory

Tortajada, C., Joshi, Y. K., \& Biswas, A. (2013). The Singapore Water Story: Sustainable Development in an Urban City-State. Routledge. https://www.routledge.com/The-SingaporeWater-Story-Sustainable-Development-in-an-Urban-City-State/Tortajada-Joshi-

Biswas/p/book/9780415657839

UNICEF, \& World Health Organization. (2019). Progress on household drinking water, sanitation and hygiene 2000-2017: In WHO. World Health Organization. http://www.who.int/water_sanitation_health/publications/jmp-report-2019/en/

Wiberg, D., Satoh, Y., Burek, P., Fischer, G., Tramberend, S., Kahil, T., Flörke, M., Eisner, S., Hanasaki, N., Wada, Y., Byers, E., Magnuszewski, P., Nava, L. F., Cosgrove, B., Langan, S., \& Scherzer, A. (2017). Water Futures and Solutions: Asia 2050 (Final Report). Knowledge and Innovation Support for the Water Financing Program of the Asian Development Bank(RETA 6498). IIASA, Laxenburg, Austria.

Wichelns, D. (2013). Enhancing the performance of water prices and tariff structures in achieving socially desirable outcomes. International Journal of Water Resources Development, 29(3), 310-326. https://doi.org/10.1080/07900627.2012.721675

World Bank. (n.d.). Singapore Overview. Retrieved May 21, 2021, from https://www.worldbank.org/en/country/singapore/overview\#2 